\title{
Effect of Partial Replacement of Forage Neutral Detergent Fiber with By-Product Neutral Detergent Fiber in Close-Up Diets on Periparturient Performance of Dairy Cows
}

\author{
H. M. Dann, ${ }^{* 1}$ M. P. Carter, ${ }^{*}$ K. W. Cotanch, ${ }^{*}$ C. S. Ballard, ${ }^{*}$ T. Takano,, and R. J. Grant ${ }^{\star}$ \\ *William H. Miner Agricultural Research Institute, Chazy, NY 12921 \\ †Zen-Noh National Federation of Agricultural Co-operative Associations, Tokyo, Japan, 100-0004
}

\begin{abstract}
The objective of this study was to determine the effect of partial replacement of forage neutral detergent fiber (NDF) with by-product NDF in close-up diets of dairy cattle on periparturient metabolism and performance. Holstein cows $(n=45)$ and heifers $(n=19)$ were fed corn silage-based diets containing 1) $30 \%$ oat hay, or 2) $15 \%$ oat hay and $15 \%$ beet pulp from $d-21$ relative to expected parturition until parturition. After parturition, all animals received the same lactation diet. Animals were group-fed from $d-21$ to -10 relative to expected parturition and fed individually from $\mathrm{d}-10$ until $14 \mathrm{~d}$ in milk. Animals were required to have at least 5 $\mathrm{d}$ of prepartum dry matter intake (DMI) data to remain on the study. Data were analyzed as a randomized design and subjected to ANOVA using the MIXED procedure of SAS. Close-up diet did not affect DMI, total tract nutrient digestibility, energy balance, or serum content of nonesterified fatty acids and $\beta$-hydroxybutyrate during the last $5 \mathrm{~d}$ prepartum. Prepartum body weight and body condition score were similar between treatments. There was no carryover effect of close-up diet on DMI, energy balance, milk yield, body weight, body condition score, or serum content of nonesterified fatty acids and $\beta$-hydroxybutyrate during the first 14 $\mathrm{d}$ in milk. In summary, partial replacement of forage NDF (oat hay) with by-product NDF (beet pulp) did not affect periparturient metabolism or performance.
\end{abstract}

Key words: intake, neutral detergent fiber, nonforage fiber source, transition cow

\section{INTRODUCTION}

The transition period of dairy cows typically is defined as $3 \mathrm{wk}$ before to $3 \mathrm{wk}$ after parturition. It is characterized by changes in the endocrine, metabolic,

Received October 19, 2006.

Accepted December 4, 2006.

Corresponding author: dann@whminer.com and immunological status of the cow as she adapts physiologically from pregnancy to lactation (Grummer, 1995; Drackley, 1999). Nutritional management during the transition period may affect susceptibility of cows to metabolic disorders and infectious diseases during the periparturient period (Grummer, 1995; Drackley, 1999). A gradual decline in DMI starts approximately 3 wk before parturition. The magnitude of the decrease in DMI can vary, but a 30\% reduction is typical (Grummer, 1995). The decrease in DMI combined with the normal homeorhetic processes cause an increase in circulating NEFA as a result of lipid mobilization from adipose tissue. Depending on the severity of the reduction in DMI and increase in NEFA, the risk of developing fatty liver, ketosis, and other associated metabolic disorders may increase significantly.

Current practice is to maximize prepartum DMI while minimizing the drop in DMI as parturition approaches. Grummer (1995) found a positive correlation between DMI at $1 \mathrm{~d}$ prepartum and DMI at $21 \mathrm{~d}$ postpartum. More recently, early postpartum DMI and hepatic lipid and triglyceride contents were determined to be more highly related to changes in DMI than to actual DMI during the prepartum period (Drackley, 2003; Mashek and Grummer, 2003). Consequently, any nutritional or management strategy that either increases DMI or prevents a decrease in DMI in the closeup cow should promote greater DMI immediately postpartum. More rapid increases in DMI postpartum will reduce the extent of lipid mobilization, reduce the severity of negative energy balance, and improve health and productivity.

Several nutritional approaches for the close-up diet have been proposed over the last $20 \mathrm{yr}$ to stimulate periparturient DMI and minimize lipid mobilization: 1) incorporate bulky forage NDF sources into the diet to increase ruminal fill, 2) increase NFC or fat content of the diet to increase energy intake, and 3) use feed additives that serve as gluconeogenic precursors to increase energy supply. These approaches have yielded variable results in research and production settings. 
Another nutritional approach that has received attention recently is the partial replacement of forage NDF in the close-up diet with more digestible NDF sources from selected by-product feeds. The NDF from by-product nonforage fiber sources (NFFS), such as soybean hulls, beet pulp, and citrus pulp is characterized by low lignin content, a rapid rate of fermentation, and a high extent of digestion. The rate of NDF digestion of NFFS is greater than the rate of NDF digestion of most forage, but less than the rate of sugar or starch fermentation, so replacing forage NDF with NFFS NDF should promote greater dietary digestibility and feed intake.

Some preliminary reports have found a positive effect of replacing forages in dry cow diets with NFFS (i.e., soybean hulls and cottonseed hulls). Underwood et al. (1998) determined the effect of partial replacement $(0$, 15,30 , or $45 \%$ ) of long-stem grass hay with soybean hulls in close-up diets fed to Holstein cows on periparturient performance. Cows were fed the same lactation diet after parturition. Cows fed diets containing soybean hulls had greater DMI prepartum but not postpartum. Cows fed the $30 \%$ soybean hull diet prepartum subsequently peaked earlier and had a higher peak milk yield than cows fed the 0 or $45 \%$ soybean hull diets. Pickett et al. (2003) fed Holstein cows, during the entire dry period, a conventional diet containing $70 \%$ forage and a diet containing NFFS for which $28 \%$ of the forage was replaced with cottonseed hulls and soybean hulls. Cows fed the diet containing NFFS had greater prepartum DMI and lower plasma NEFA compared with cows fed the conventional diet. However, diet did not affect postpartum feed intake, plasma NEFA, or milk yield. Smith et al. (2005) fed close-up cows a high NFC diet or a high NFFS diet (essentially isocaloric). The NFFS (9.5\% beet pulp and $7.9 \%$ soybean hulls) replaced starch-based cereals. There was no effect of diet on prepartum and postpartum DMI or milk yield. It appears that feeding close-up diets containing NFFS in place of forage NDF may stimulate DMI of closeup cows compared with close-up diets containing large amounts of poor or average quality forages, but not when NFFS NDF replaces starch-based cereals. None of the studies evaluated how inclusion of NFFS in dry cow diets may have affected ruminal digestion kinetics, passage rate, or total tract digestibility of nutrients.

The objective of this study was to determine the effect of partial replacement of forage NDF with by-product NDF in close-up diets on periparturient metabolism and lactational performance. Specifically, this study determined the effect of feeding a close-up diet containing $30 \%$ oat hay compared with a diet containing $15 \%$ oat hay and $15 \%$ beet pulp on DMI, serum NEFA and BHBA concentrations, BW, BCS, milk yield, and health disorders of primiparous and multiparous Holstein cows. In
Table 1. Ingredient composition (DM basis) of diets fed to Holstein cows and heifers during the close-up and lactating periods

\begin{tabular}{|c|c|c|c|}
\hline \multirow[b]{2}{*}{ Ingredient (\% of DM) } & \multicolumn{2}{|c|}{ Close-up diet } & \multirow{2}{*}{$\begin{array}{c}\text { Lactation } \\
\text { diet }\end{array}$} \\
\hline & Control & Beet pulp & \\
\hline Corn silage, dual purpose & 34.59 & 34.59 & - \\
\hline Corn silage, brown midrib & - & - & 38.40 \\
\hline Alfalfa-grass silage & - & - & 13.57 \\
\hline Oat hay & 30.26 & 15.13 & - \\
\hline Beet pulp & - & 15.13 & 10.24 \\
\hline Grass hay & - & - & 5.12 \\
\hline Cottonseed & - & - & 1.92 \\
\hline Canola meal & 12.33 & 12.33 & - \\
\hline Soybean hulls & 10.11 & 10.11 & 7.34 \\
\hline Soybean meal, $55 \%$ CP & 5.14 & 5.14 & 10.07 \\
\hline Corn meal & 4.58 & 4.58 & 5.59 \\
\hline Corn gluten meal & 0.34 & 0.34 & 0.81 \\
\hline AminoPlus $^{1}$ & 0.30 & 0.30 & 2.88 \\
\hline Molasses & - & - & 0.87 \\
\hline Megalac- $\mathrm{R}^{2}$ & - & - & 0.64 \\
\hline Alimet $^{3}$ & - & - & 0.04 \\
\hline Reashure choline ${ }^{4}$ & 0.56 & 0.56 & 0.31 \\
\hline Calcium carbonate & 0.64 & 0.64 & 0.59 \\
\hline Sodium bicarbonate & - & - & 0.41 \\
\hline Sodium chloride & 0.47 & 0.47 & 0.46 \\
\hline Magnesium oxide & 0.30 & 0.30 & 0.13 \\
\hline Dicalcium phosphate & - & - & 0.38 \\
\hline Calcium sulfate & - & - & 0.08 \\
\hline Trace minerals ${ }^{5}$ & 0.01 & 0.01 & 0.01 \\
\hline Organic trace minerals ${ }^{6}$ & 0.03 & 0.03 & 0.04 \\
\hline Selenium ${ }^{7}$ & 0.03 & 0.03 & 0.03 \\
\hline Vitamin $\mathrm{E}^{8}$ & 0.27 & 0.27 & 0.07 \\
\hline Vitamins $\mathrm{A}, \mathrm{D}$, and $\mathrm{E}^{9}$ & 0.03 & 0.03 & 0.01 \\
\hline
\end{tabular}

${ }^{1}$ Ag Processing Inc., Omaha, NE.

${ }^{2}$ Church \& Dwight Co., Inc., Princeton, NJ.

${ }^{3}$ Novus International, Inc., St. Louis, MO.

${ }^{4}$ Balchem Corporation, New Hampton, NY.

${ }^{5}$ Contained 25,000 mg Fe/kg, 4,166 mg Zn/kg, 20,833 mg Cu/kg, $25,000 \mathrm{mg} \mathrm{Mn} / \mathrm{kg}, 416 \mathrm{mg} \mathrm{Se} / \mathrm{kg}$, and 2,083 mg I/kg.

${ }^{6}$ Contained $1.0 \% \mathrm{Ca}, 8.8 \% \mathrm{~S}, 4,102 \mathrm{mg} \mathrm{Fe} / \mathrm{kg}, 2,045 \mathrm{mg} \mathrm{Zn} / \mathrm{kg}$, $20,425 \mathrm{mg} \mathrm{Cu} / \mathrm{kg}, 31,681 \mathrm{mg} \mathrm{Mn} / \mathrm{kg}, 1,549 \mathrm{mg} \mathrm{Co} / \mathrm{kg}$, and 1,419 mg $\mathrm{I} / \mathrm{kg}$.

${ }^{7}$ Contained $606 \mathrm{mg} \mathrm{Se} / \mathrm{kg}$ and $364 \mathrm{~g} \mathrm{Ca} / \mathrm{kg}$.

${ }^{8}$ Contained 44,647 IU vitamin E/kg.

${ }^{9}$ Contained 74,960 kIU vitamin $\mathrm{A} / \mathrm{kg}, 13,897 \mathrm{kIU}$ vitamin $\mathrm{D} / \mathrm{kg}$, and $92,858 \mathrm{IU}$ vitamin $\mathrm{E} / \mathrm{kg}$.

addition, ruminal NDF digestion kinetics and total tract digestibility of nutrients were determined.

\section{MATERIALS AND METHODS}

\section{Experimental Design and Management of Cows}

Holstein cows $(\mathrm{n}=45)$ and heifers $(\mathrm{n}=19)$ were utilized in a completely randomized design to test the effects of 2 dietary treatments (Table 1): a high-forage diet (control; $\mathrm{n}=31$ animals) and a diet with partial replacement of forage with by-product NFFS (beet pulp; $\mathrm{n}=33$ animals). Animals were fed the dietary treatments during the close-up period from $-21 \pm 3 \mathrm{~d}$ relative to expected parturition until parturition. After parturi- 
tion, all animals received a common lactation diet (Table 1).

The control diet was formulated to supply adequate ME and MP for a close-up dry cow with a BCS of 3.75, a BW of $568 \mathrm{~kg}$, and a DMI of $10.5 \mathrm{~kg} / \mathrm{d}$ (CPM-Dairy nutrition model; version 3.0; Cornell University, Ithaca, NY, University of Pennsylvania, Philadelphia, PA; William H. Miner Agricultural Research Institute, Chazy, NY). The beet pulp diet was similar to the control diet except that beet pulp replaced a portion of the oat hay. The lactation diet was formulated for a cow 15 DIM with a BCS of 3.5 , a BW of $648 \mathrm{~kg}$, a DMI of $18.4 \mathrm{~kg} /$ $\mathrm{d}$, and a milk yield of $29.5 \mathrm{~kg} / \mathrm{d}$ containing $3.6 \%$ fat and $3.0 \%$ protein (CPM-Dairy; version 3.0 ). The diets were fed as TMR.

Animals were housed in 2 pens in a freestall barn (William H. Miner Agricultural Research Institute, Chazy, NY) from $-21 \pm 3$ to $-10 \mathrm{~d}$ relative to expected parturition. The pens were comparable in size with similar animal density, bunk space, stall design, flooring, and water accessibility. Animals were group-fed by treatment of ad libitum intake (approximately $1.05 \times$ expected intake) once daily $(1100 \mathrm{~h})$. Animals were group-fed until $-10 \mathrm{~d}$ relative to expected parturition. At that time, animals were moved to individual pens or tie-stalls and fed individually $(1100 \mathrm{~h})$ until parturition. After parturition until 14 DIM, animals were housed in tie-stalls equipped with individual feed boxes. Animals were fed a common fresh cow diet for ad libitum intake (approximately $1.05 \times$ expected intake) once daily (0900 h).

Cows were removed from the barn 3 times daily (0030, 0830, and $1630 \mathrm{~h})$ for milking in a double-12 parallel milking parlor (Xpressway Parallel Stall System; Bou-Matic, Madison, WI).

\section{Data Collection, Sampling Procedures, and Analytical Methods}

Feed ingredients were sampled weekly. A portion of each sample was dried in a forced-air oven at $105^{\circ} \mathrm{C}$ for 18 to $24 \mathrm{~h}$ to determine DM content. Then, diets were adjusted to reflect changes in DM content. The remainder of each sample was dried in a forced-air oven at $60^{\circ} \mathrm{C}$ for $48 \mathrm{~h}$, ground to pass through a $4-\mathrm{mm}$ screen (Wiley mill; Arthur H. Thomas, Philadelphia, PA), and composited. A study composite for each feed ingredient was submitted to a commercial laboratory for wet chemistry analysis (model profile; Dairy One Cooperative Inc., Ithaca, NY; Table 2). Dry matter (method 930.15), CP (method 990.03), and ash (method 942.05) were determined according to AOAC (2000) methods. Soluble protein was determined with a sodium borate, sodium phosphate buffer procedure (Roe and Sniffen, 1990).
Nonstructural carbohydrates and sugars were determined by the procedures of Hall et al. (1999) and Smith (1969) where ferricyanide was used to detect reducing sugars. Starch was determined with a YSI 2700 Select biochemistry analyzer (Application note 319; YSI Inc., Yellow Springs, $\mathrm{OH}$ ). Acid detergent fiber with residual ash, NDF with residual ash (using $\alpha$-amylase and sodium sulfite), and acid detergent lignin (ADL) were determined by the Ankom $\mathrm{A}^{200}$ filter bag technique (Ankom Technology Corp., Fairport, NY; Van Soest et al., 1991). Neutral detergent insoluble CP (NDICP) and acid detergent insoluble CP (ADICP) were determined by analyzing NDF and ADF residues for Kjeldahl N (Licitra et al., 1996). Ether extract was measured using the automated Tecator Soxtec System HT6 (Application note AN 301; Foss North America, Eden Prairie, MN). Calcium, $\mathrm{P}, \mathrm{Mg}, \mathrm{K}, \mathrm{Na}, \mathrm{Fe}, \mathrm{Zn}, \mathrm{Cu}, \mathrm{Mn}$, and Mo were measured using a Thermo Jarrell Ash IRIS Advantage Inductively Coupled Plasma Radial Spectrometer (model ICAP 61; Thermo Jarrell Ash, Ithaca, NY; Sirois et al., 1994). Sulfur was measured using an elemental analyzer (Application note form 203-601-229, 08/92; model SC-432; Leco Corp., St. Joseph, MI; Sirois et al., 1994). The chloride ion was measured using a potentiometric titrator (Application bulletin 130; Brinkmann Metrohm 716 Titrino titration unit with silver electrode; Brinkmann Instruments, Inc., Westbury, NY). Nonfiber carbohydrate was calculated as $100-[\mathrm{CP}+$ $(\mathrm{NDF}-\mathrm{NDICP})+$ ether extract + ash].

Diets and orts were sampled daily. A portion of each sample was dried in a forced-air oven at $105^{\circ} \mathrm{C}$ for 18 to $24 \mathrm{~h}$ to determine DM content. The remainder of each diet and ort sample was stored at $-20^{\circ} \mathrm{C}$, and then composited by week. A portion of each weekly diet composite was dried in a forced-air oven at $60^{\circ} \mathrm{C}$ for $48 \mathrm{~h}$, ground to pass through a 4-mm screen (Wiley mill; Arthur H. Thomas), and composited by 4 -wk periods. Four-week composite samples of each diet were submitted for wet chemistry analysis (model profile; Dairy One Cooperative Inc.; Table 3) as previously described. Another portion of each weekly diet composite sample was used to determine particle size distribution on an as-fed basis with a Penn State Particle Separator (Lammers et al., 1996; Table 4). Each weekly ort composite sample (by cow) was used to determine particle size distribution on an as-fed basis with a Penn State Particle Separator (Lammers et al., 1996). Particle size distribution of diets and orts were compared to determine if sorting occurred ( $\geq 15$ percentage unit change on the 19-mm screen).

Dry matter intake of individual animals was determined from $-10 \mathrm{~d}$ relative to expected parturition until 14 DIM. Each animal was required to have at least 5 d of prepartum intake data to remain on the study. 
Table 2. Analyzed chemical composition (DM basis) of ingredients fed to Holstein cows and heifers during the close-up and lactating periods

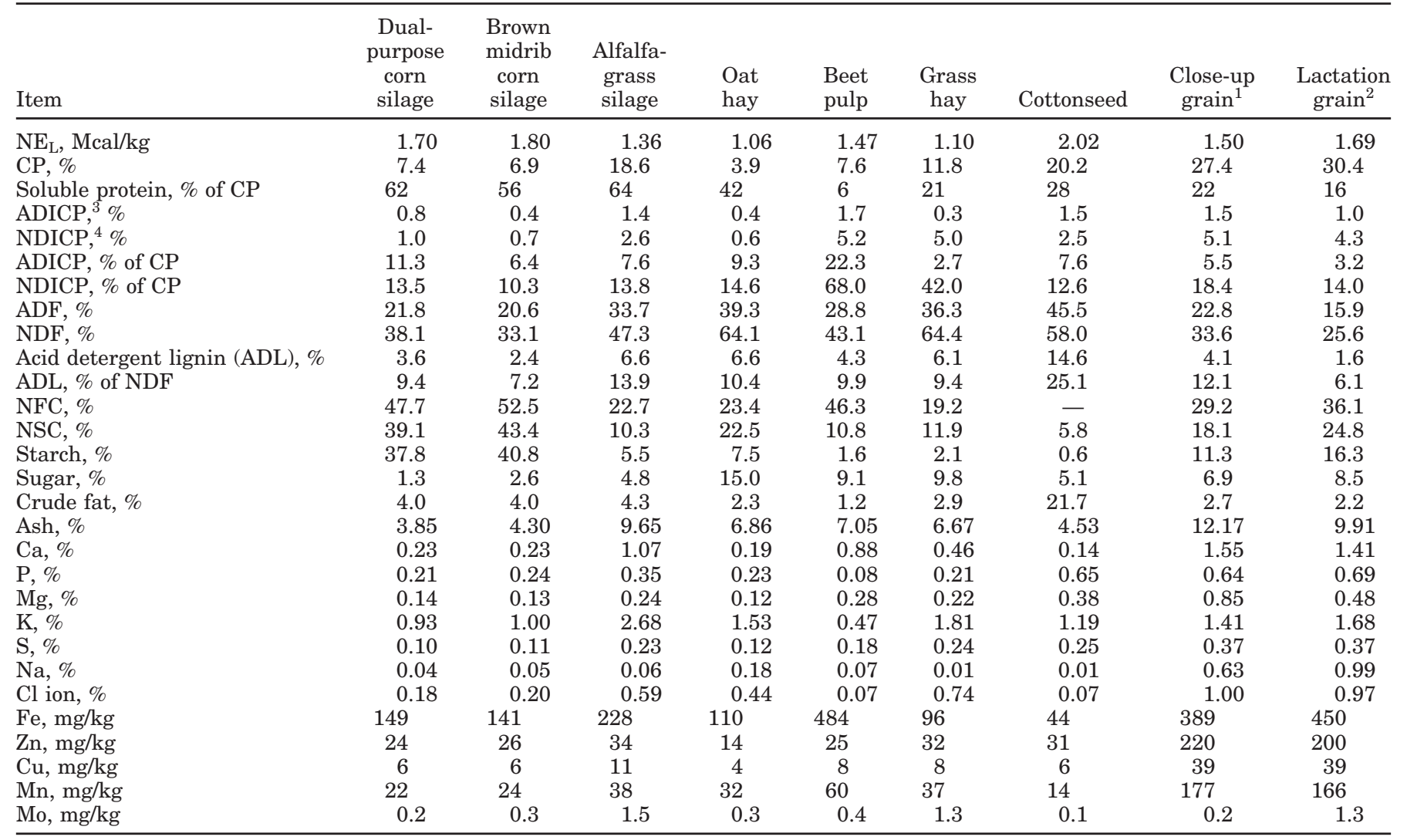

${ }^{1}$ Contained $35.66 \%$ canola meal, $29.22 \%$ soybean hulls, $14.86 \%$ soybean meal, $13.25 \%$ corn meal, $0.99 \%$ corn gluten meal, $0.87 \%$ AminoPlus, $1.86 \%$ calcium carbonate, $1.36 \%$ sodium chloride, $0.87 \%$ magnesium oxide, $0.04 \%$ trace mineral, $0.10 \%$ organic trace minerals, $0.10 \%$ selenium, $0.77 \%$ vitamin $\mathrm{E}$, and $0.07 \%$ vitamins $\mathrm{A}, \mathrm{D}$, and $\mathrm{E}$.

${ }^{2}$ Contained $24.63 \%$ soybean hulls, $33.79 \%$ soybean meal, $18.76 \%$ corn meal, $2.71 \%$ corn gluten meal, $9.68 \%$ AminoPlus, $2.90 \%$ molasses, $0.13 \%$ Alimet, $1.97 \%$ calcium carbonate, $1.37 \%$ sodium bicarbonate, $1.54 \%$ sodium chloride, $0.44 \%$ magnesium oxide, $1.28 \%$ dicalcium phosphate, $0.28 \%$ calcium sulfate, $0.05 \%$ trace minerals, $0.12 \%$ organic trace minerals, $0.09 \%$ selenium, $0.22 \%$ vitamin $\mathrm{E}$, and $0.04 \%$ vitamins $\mathrm{A}, \mathrm{D}$, and $\mathrm{E}$.

${ }^{3}$ Acid detergent insoluble CP.

${ }^{4}$ Neutral detergent insoluble CP.

Body weight was measured and BCS was assigned in 0.25-unit increments on a 1-to-5 scale (Ferguson et al., 1994) for each cow weekly from $-21 \mathrm{~d}$ relative to expected parturition (start of study) to 14 DIM. Also, BW and BCS were recorded within $12 \mathrm{~h}$ of parturition. Two individuals assigned BCS independently at each time of scoring throughout the study. Calves were weighed at birth.

Milk yields were recorded electronically (ProVantage Information Management System; Bou-Matic) from parturition to $14 \mathrm{~d}$ postpartum. Milk samples from 3 consecutive milkings for each animal were collected between 7 and 10 DIM and 11 and 14 DIM. The 3 consecutive milk samples were composited in proportion to milk yield at each sampling and preserved (Bronolab-W II Liquid Preservative; D\&F Control Systems, Inc., Dublin, CA). The composited milk samples were analyzed
(Dairy One Cooperative Inc.) for fat, true protein, lactose, solids nonfat, urea $\mathrm{N}$, and somatic cells by infrared procedures (Foss 4000; Foss Technology).

Ruminal in situ degradation of DM and NDF of oat hay, beet pulp, and close-up diets were determined in 7 ruminally cannulated (Bar Diamond, Inc., Parma, ID) multiparous lactating Holstein cows (4 cows from the control group and 3 cows from the beet pulp group). Cows were moved to tie-stalls at $-10 \mathrm{~d}$ relative to expected parturition. Samples of ingredients and diets were dried in a forced-air oven at $60^{\circ} \mathrm{C}$ for $48 \mathrm{~h}$, ground to pass through a 2-mm screen (Wiley mill; Arthur H. Thomas), and incubated in $\mathrm{N}$-free polyester in situ bags ( $5 \mathrm{~g} ; 10 \mathrm{~cm} \times 20 \mathrm{~cm}, 50-\mu \mathrm{m}$ pore size; Ankom Technology Corp.) for $0,12,24,48$, and $96 \mathrm{~h}$ starting at $-9 \mathrm{~d}$ relative to expected parturition. Duplicate bags were used for the 0-, 12-, 24-, and 48-h time points and triplicate bags 
Table 3. Analyzed chemical composition (mean \pm standard error; DM basis) of diets fed to Holstein cows and heifers during the close-up and lactating periods

\begin{tabular}{|c|c|c|c|}
\hline \multirow[b]{2}{*}{ Item } & \multicolumn{2}{|c|}{ Close-up diet } & \multirow[b]{2}{*}{ Lactation diet } \\
\hline & Control & Beet pulp & \\
\hline Samples, n & 7 & 7 & 7 \\
\hline $\mathrm{NE}_{\mathrm{L}}, \mathrm{Mcal} / \mathrm{kg}$ & $1.60 \pm 0.02$ & $1.60 \pm 0.01$ & $1.71 \pm 0.01$ \\
\hline $\mathrm{CP}, \%$ & $12.8 \pm 0.3$ & $13.2 \pm 0.2$ & $17.1 \pm 0.1$ \\
\hline Soluble protein, \% of CP & $32.6 \pm 1.7$ & $34.4 \pm 2.2$ & $33.3 \pm 2.3$ \\
\hline $\mathrm{ADICP},{ }^{1} \%$ & $0.4 \pm 0.1$ & $0.6 \pm 0.1$ & $0.5 \pm 0.1$ \\
\hline NDICP, ${ }^{2} \%$ & $2.4 \pm 0.1$ & $2.8 \pm 0.1$ & $2.8 \pm 0.1$ \\
\hline $\mathrm{ADICP}, \%$ of $\mathrm{CP}$ & $3.4 \pm 0.2$ & $4.8 \pm 0.4$ & $3.1 \pm 0.1$ \\
\hline NDICP, \% of CP & $18.7 \pm 0.3$ & $21.4 \pm 0.5$ & $16.4 \pm 0.7$ \\
\hline $\mathrm{ADF}, \%$ & $26.1 \pm 0.9$ & $25.0 \pm 0.4$ & $21.0 \pm 0.3$ \\
\hline $\mathrm{NDF}, \%$ & $42.4 \pm 0.8$ & $40.5 \pm 0.6$ & $35.0 \pm 0.4$ \\
\hline Acid detergent lignin (ADL), \% & $3.5 \pm 0.2$ & $3.6 \pm 0.2$ & $2.9 \pm 0.1$ \\
\hline $\mathrm{ADL}, \%$ of $\mathrm{NDF}$ & $8.3 \pm 0.4$ & $9.0 \pm 0.4$ & $8.4 \pm 0.4$ \\
\hline $\mathrm{NFC}, \%$ & $36.9 \pm 0.5$ & $39.4 \pm 0.6$ & $39.1 \pm 0.4$ \\
\hline NSC, \% & $25.4 \pm 0.8$ & $24.7 \pm 0.4$ & $25.9 \pm 0.5$ \\
\hline Starch, \% & $18.9 \pm 0.7$ & $18.3 \pm 0.4$ & $21.3 \pm 0.6$ \\
\hline Sugar, \% & $6.5 \pm 0.6$ & $6.4 \pm 0.3$ & $4.6 \pm 0.1$ \\
\hline Crude fat, \% & $3.5 \pm 0.1$ & $3.2 \pm 0.1$ & $4.6 \pm 0.1$ \\
\hline Ash, \% & $6.76 \pm 0.06$ & $6.55 \pm 0.08$ & $7.07 \pm 0.03$ \\
\hline $\mathrm{Ca}, \%$ & $0.63 \pm 0.03$ & $0.70 \pm 0.01$ & $0.79 \pm 0.02$ \\
\hline $\mathrm{P}, \%$ & $0.33 \pm 0.01$ & $0.32 \pm 0.01$ & $0.38 \pm 0.01$ \\
\hline $\mathrm{Mg}, \%$ & $0.35 \pm 0.01$ & $0.37 \pm 0.01$ & $0.28 \pm 0.01$ \\
\hline $\mathrm{K}, \%$ & $1.15 \pm 0.01$ & $1.00 \pm 0.01$ & $1.36 \pm 0.04$ \\
\hline $\mathrm{S}, \%$ & $0.20 \pm 0.01$ & $0.20 \pm 0.01$ & $0.22 \pm 0.01$ \\
\hline $\mathrm{Na}, \%$ & $0.24 \pm 0.02$ & $0.25 \pm 0.02$ & $0.43 \pm 0.01$ \\
\hline $\mathrm{Cl}$ ion, \% & $0.54 \pm 0.01$ & $0.51 \pm 0.01$ & $0.55 \pm 0.01$ \\
\hline $\mathrm{Fe}, \mathrm{mg} / \mathrm{kg}$ & $450 \pm 24$ & $528 \pm 30$ & $361 \pm 16$ \\
\hline $\mathrm{Zn}, \mathrm{mg} / \mathrm{kg}$ & $75 \pm 2$ & $81 \pm 1$ & $80 \pm 3$ \\
\hline $\mathrm{Cu}, \mathrm{mg} / \mathrm{kg}$ & $14 \pm 1$ & $16 \pm 1$ & $17 \pm 1$ \\
\hline $\mathrm{Mn}, \mathrm{mg} / \mathrm{kg}$ & $67 \pm 1$ & $72 \pm 1$ & $70 \pm 2$ \\
\hline Mo, mg/kg & $0.7 \pm 0.1$ & $0.5 \pm 0.1$ & $1.0 \pm 0.1$ \\
\hline
\end{tabular}

${ }^{1}$ Acid detergent insoluble CP.

${ }^{2}$ Neutral detergent insoluble CP.

were used for the 96 -h time point. A laboratory standard was incubated in duplicate bags at $24 \mathrm{~h}$ to monitor variation among runs. Bags with no sample (blank) were incubated at all time points. In situ bags (with and without sample) were presoaked for $20 \mathrm{~min}$ in $39^{\circ} \mathrm{C}$ water, placed in mesh bags, and suspended in the ventral rumen. In situ bags were inserted in reverse order, removed from the rumen simultaneously, hand rinsed with water, dried in a forced-air oven at $60^{\circ} \mathrm{C}$ for $48 \mathrm{~h}$,

Table 4. Particle size distribution (mean \pm standard error) of diets fed to Holstein cows and heifers during the close-up and lactating periods

\begin{tabular}{lccr}
\hline & \multicolumn{2}{c}{ Close-up diet } \\
\cline { 2 - 3 } Item & Control & Beet pulp & Lactation diet \\
\hline Samples, $\mathrm{n}$ & 27 & 28 & 27 \\
Particle size $^{1}$ & \multicolumn{2}{c}{$\%$ retained (as-fed basis) } \\
\cline { 2 - 3 }$>19 \mathrm{~mm}$ & $19.4 \pm 0.8$ & $12.1 \pm 0.7$ & $7.4 \pm 0.6$ \\
8 to $19 \mathrm{~mm}$ & $32.0 \pm 0.6$ & $39.1 \pm 0.7$ & $43.6 \pm 0.7$ \\
$<8 \mathrm{~mm}$ & $48.6 \pm 0.7$ & $48.8 \pm 0.7$ & $49.0 \pm 0.5$ \\
\hline
\end{tabular}

${ }^{1}$ Determined using the Penn State Particle Separator (Lammers et al., 1996). and weighed. Contents were analyzed for DM (forcedair oven at $60^{\circ} \mathrm{C}$ for $48 \mathrm{~h}$ ) and NDF with residual ash (using $\alpha$-amylase and without sodium sulfite; Van Soest et al., 1991; Ankom $\mathrm{A}^{200}$ Fiber Analyzer filter bag technique; Ankom Technology Corp.). Digestion kinetics [lag, fractional rate of digestion $\left(\mathrm{k}_{\mathrm{d}}\right)$, and potential extent of digestion] for DM and NDF were calculated according to the model described by Mertens and Loften (1980): $\mathrm{Y}=\mathrm{D}_{0} \mathrm{e}^{-\mathrm{kd}(\mathrm{t}-\mathrm{L})}+\mathrm{I}$, where $\mathrm{Y}=$ residue remaining at time $t, \mathrm{D}_{0}=$ potentially digestible fraction, $\mathrm{k}_{\mathrm{d}}=$ fractional rate constant of digestion, $t=$ time of fermentation, $\mathrm{L}=$ discrete lag, and $\mathrm{I}=$ indigestible fraction at $96 \mathrm{~h}$.

Total tract digestibility of $\mathrm{DM}, \mathrm{OM}, \mathrm{CP}, \mathrm{NDF}, \mathrm{ADF}$, and starch was determined on $\mathrm{d}-9$ to -5 for 14 cows and 8 heifers (11 animals per treatment). Samples of diets and orts were collected on $d-9$ to -6 and $d-8$ to -5 , respectively. Fecal grab samples were collected twice daily $(0800$ and $1600 \mathrm{~h})$ on $\mathrm{d}-8$ to -5 . Fecal samples from each cow were composited by combining approximately $100 \mathrm{~g}$ of feces from each time point. Samples of diets, orts, and feces were frozen at $-20^{\circ} \mathrm{C}$, dried in a forced-air oven at $60^{\circ} \mathrm{C}$ for $48 \mathrm{~h}$, ground to pass 
through a 1-mm screen (Wiley mill; Arthur H. Thomas), and submitted for wet chemistry analysis (Dairy One Cooperative Inc.). Composite samples (by animal) of diets, orts, and feces were analyzed for DM, ash, CP, $\mathrm{NDF}, \mathrm{ADF}$, and starch as described previously. Indigestible NDF was used as an internal marker. Indigestible NDF residue in diets, orts, and feces was quantified as NDF content of samples following an in vitro fermentation (Daisy ${ }^{\mathrm{II}}$ Incubator; Ankom Technology Corp.) in buffered rumen medium (Goering and Van Soest, 1970) for $120 \mathrm{~h}$. Total tract digestibility was calculated by the ratio technique using the concentrations of the nutrients and indigestible NDF in the diet and feces (Maynard et al., 1979). The nutrient content of the diet used in the digestibility calculation was adjusted for each cow based on the nutrient composition of the diet offered and refused. Thus, a calculated nutrient content of the consumed diet was used.

Blood $(20 \mathrm{~mL})$ was sampled from the coccygeal vein or artery at approximately $-21 \mathrm{~d}$ relative to expected parturition (start of study); daily from $-10 \mathrm{~d}$ relative to expected parturition to $7 \mathrm{DIM}$; and at 9,11 , and 13 DIM. Samples were collected before feeding $(1000 \mathrm{~h}$ prepartum and $0800 \mathrm{~h}$ postpartum) into evacuated serum tubes containing clot activator (SST tube; Becton Dickinson Vacutainer Systems, Franklin Lakes, NJ). Serum was obtained by centrifugation at $1,300 \times$ g for 15 min. Aliquots of serum were frozen at $-20^{\circ} \mathrm{C}$. A subset of samples (approximately $-21 \mathrm{~d}$ relative to expected parturition and $-5,-3,-1,1,3,5,7,9,11$, and $13 \mathrm{~d}$ relative to actual parturition) was analyzed for serum content of NEFA (NEFA C kit; Wako Chemicals USA, Inc., Richmond, VA) and BHBA ( $\beta$-HBA kit; Catachem Inc., Bridgeport, CT) using an auto analyzer (Olympus AU640 Chemistry Immuno Analyzer; Olympus America Inc., Melville, NY) at a diagnostic laboratory (Michigan State University Clinical Pathology Laboratory, East Lansing).

Health records were maintained for all animals during the study. Physical examinations were conducted daily from 1 to 10 DIM. The physical examination included evaluation of attitude; behavior; rectal temperature; urine ketone concentration (dipstick test; Labstix; Bayer Corporation, Elkhart, IN); rumen fill; abdominal pings; vaginal discharge; presences of fetal membranes; fecal score; mammary gland appearance; and mammary secretions.

Energy balance was calculated individually for each cow according to NRC (2001). All equations used units of megacalories per kilogram. Net energy intake $\left(\mathbf{N E}_{\mathbf{I}}\right)$ was determined by multiplying DMI by the mean $\mathrm{NE}_{\mathrm{L}}$ density of the diet. Net energy required for maintenance $\left(\mathrm{NE}_{\mathrm{M}}\right)$ was calculated as $\mathrm{BW}^{0.75} \times 0.08$. Net energy required for pregnancy $\left(\mathbf{N E}_{\mathbf{P}}\right)$ was calculated as [ $(0.00318$ $\times$ day of gestation -0.0352$) \times($ calf birth weight/45)]/ 0.218 . Net energy required for lactation $\left(\mathrm{NE}_{\mathrm{L}}\right)$ was calculated as $(0.0929 \times$ fat $\%+0.0563 \times$ protein $\%+0.0395$ $\times$ lactose $\%) \times$ milk. The equation used to calculate prepartum energy balance was $\mathrm{EB}_{\mathrm{PRE}}=\mathrm{NE}_{\mathrm{I}}-\left(\mathrm{NE}_{\mathrm{M}}+\right.$ $\mathrm{NE}_{\mathrm{P}}$ ). The equation used to calculate postpartum energy balance was $\mathrm{EB}_{\mathrm{POST}}=\mathrm{NE}_{\mathrm{I}}-\left(\mathrm{NE}_{\mathrm{M}}+\mathrm{NE}_{\mathrm{L}}\right)$. Energy balance was expressed as percentage of requirement.

\section{Statistical Analysis}

Of the 71 cows and 28 heifers originally enrolled in the study, only 45 cows and 19 heifers were used in the analyses. Thirty-three animals were removed from the study because they were on the close-up diet for less than $14 \mathrm{~d}$ and had less than $5 \mathrm{~d}$ of individual feed intake. One animal developed prepartum mastitis (unrelated to dietary treatment) and was removed from the study. Another animal was removed from the study because of a management error (housed in a location with nonstudy feed).

Data from the close-up period ( $-21 \mathrm{~d}$ before expected parturition to parturition; $-5 \mathrm{~d}$ before parturition to parturition), and postpartum period (1 to 7 DIM; 1 to 14 DIM) were analyzed separately to focus on critical times when metabolic changes are most evident. Data were analyzed as a randomized design. Statistical computations were performed using SAS software (version 8.2; SAS Institute Inc., Cary, NC). Data measured over time were subjected to ANOVA by using the REPEATED statement in the MIXED procedure of SAS (Littell et al., 1996). The model contained the effect of close-up treatment (control and beet pulp diets), parity, time, time by treatment interaction, and time by parity interaction. Animal nested within close-up treatment and parity was designated as a random effect and was used as the error term. For each variable analyzed, animal nested within treatment and parity was subjected to 3 covariance structures: compound symmetry, autoregressive order 1 , and unstructured covariance. The covariance structure that resulted in the Akaike's information criterion closest to zero was used (Littell et al., 1996). Data for serum NEFA and BHBA, BW, and BCS were adjusted by analysis of covariance using the respective measurements obtained at $-21 \mathrm{~d}$ before expected parturition (start of study). Data not analyzed over time were subjected to ANOVA by using the MIXED procedure of SAS (Littell et al., 1996). The model contained the effect of close-up treatment (control and beet pulp diets) and parity. Animal nested within close-up treatment and parity was designated as a random effect. Least squares means were reported for all ANOVA results. Health data were analyzed by Fisher's Exact Test using the FREQ procedure of SAS 
with the exact option (Hatcher and Stepanski, 1994). Significance was declared at $P<0.05$ and trends at $P$ $<0.10$.

\section{RESULTS AND DISCUSSION}

\section{Diets}

The control and beet pulp diets were similar in ingredient composition except the substitution of beet pulp for a portion of the oat hay (Table 1). Soybean hulls, another source of NFFS, was in both close-up diets at $10 \%$ of DM. Silage quality was typical of the northern New York region (Table 2). Oat hay and beet pulp had an average chemical composition based on the Dairy One feed composition library (Dairy One, 2006) except that both ingredients had a slightly lower CP content than the library values (Table 2 ).

There was less difference in the actual nutrient composition of the control and beet pulp diets than was formulated originally. In particular, the soluble fiber content of the formulated control and beet pulp diets was 4.5 and $9.1 \%$ of DM, respectively. Beet pulp is unique in its high content of soluble fiber, especially pectic substances. Neutral detergent fiber in beet pulp can be digested more quickly than forage NDF. In addition, pectin is degraded more rapidly than cellulose and hemicellulose. The soluble fiber content of the diets fed in this study was estimated as the difference between NFC and NSC. The estimated neutral-detergent soluble fiber content of the control diet and beet pulp diets was 11.5 and $14.7 \%$ of DM, respectively, resulting in a higher content than formulated in both diets with a smaller difference between diets (formulated difference: 4.6 vs. estimated difference: 3.2 ).

The beet pulp diet was expected to have a greater rate of dietary digestibility than the oat hay because typically the rate of NDF digestion of NFFS is greater than the rate of NDF digestion of forages. In situ digestion kinetic data supported this concept (Table 5). Oat hay had a mean fractional rate and potential extent of digestion for NDF of $0.026 \mathrm{~h}^{-1}$ and $51.7 \%$, respectively. Beet pulp had a mean fractional rate and potential extent of digestion for NDF of $0.088 \mathrm{~h}^{-1}$ and $85.3 \%$, respectively. Thus, the control diet had a lower mean potential extent of digestion for NDF than the beet pulp $\operatorname{diet}(64.9$ vs. $71.9 \%)$.

As expected, the control diet had more large ( $>19$ $\mathrm{mm}$ ) particles than the beet pulp diet (Table 4) in part due to the higher inclusion level of oat hay in the control diet. The beet pulp was pelleted, which resulted in more medium ( 8 to $19 \mathrm{~mm}$ ) particles in the beet pulp diet (Table 4). The proportion of small $(<8 \mathrm{~mm})$ particles was similar between diets. When the particle size distribution of diets and orts was compared, it was evident that some animals sorted. Nine of 31 cows fed the control diet had a difference of $\geq 15$ percentage units between samples of diet and orts for large $(>19 \mathrm{~mm})$ particles, indicating that some cows sorted against the oat hay. In contrast, no cows fed the beet pulp diet had a difference of $\geq 15$ percentage units between samples of diet and orts for large $(>19 \mathrm{~mm})$ particles.

\section{Prepartum Performance}

At the start of the study, BW (mean \pm SE; $767 \pm 11$ $\mathrm{kg}), \mathrm{BCS}(3.53 \pm 0.04)$, serum content of NEFA (144 \pm $10 \mu \mathrm{Eq} / \mathrm{L})$ and BHBA $(4.8 \pm 0.2 \mathrm{mg} / \mathrm{dL})$, and lactation number for the upcoming lactation $(2.0 \pm 0.1)$ were similar $(P>0.10)$ between dietary treatment groups. Animals averaged $21.1 \pm 0.5 \mathrm{~d}$ on the close-up diets.

Dry matter intake, energy balance, and serum content of NEFA and BHBA during the last $5 \mathrm{~d}$ of gestation were not affected by close-up diet $(P>0.10$; Table 6$)$. Animals consumed approximately $1.5 \%$ of BW and were in positive energy balance (Table 6). Dry matter intake decreased $19 \%$ during the last $5 \mathrm{~d}$ of gestation with $72 \%$ of the decrease in DMI occurring the day before parturition. Animals fed the beet pulp diet compared with the control diet tended $(P=0.08$; Table 6$)$ to have a greater change in DMI. Close-up cows usually experience a gradual decline in DMI that starts approximately $3 \mathrm{wk}$ before parturition. The magnitude of the decrease can vary, but a 30\% reduction is typical (Grummer, 1995; Ingvartsen and Andersen, 2000). Cows consumed approximately $2 \mathrm{~kg} / \mathrm{d}$ more DMI than heifers $(P=0.004)$. However, DMI expressed as a percentage of BW was similar $(P=0.13)$ between cows and heifers because heifers had lower BW. Energy balance tended to be greater $(P=0.08)$ for cows $(120 \%)$ than heifers $(110 \%)$. Heifers, but not cows, were in negative energy balance (94\%) $1 \mathrm{~d}$ prepartum. During the last $5 \mathrm{~d}$ of gestation, serum content of NEFA and BHBA increased 79 and $27 \%$, respectively $(P<0.001$; Table 6) as expected (Vazquez-Añon et al., 1994; Grummer, 1995). Surprisingly, there was a greater increase in BHBA $(P=0.03)$ for heifers $(31 \%)$ than cows $(25 \%)$. However, the mean content of BHBA at $1 \mathrm{~d}$ prepartum in heifers $(7.1 \mathrm{mg} / \mathrm{dL})$ and cows $(6.6 \mathrm{mg} / \mathrm{dL})$ was below $14.4 \mathrm{mg} / \mathrm{dL}$, which was considered the threshold for subclinical ketosis in this study. Additionally, serum content of BHBA did not exceed $14.4 \mathrm{mg} / \mathrm{dL}$ for any heifers or cows during the last $5 \mathrm{~d}$ of gestation. The reason for the greater increase of BHBA before parturition in heifers compared with cows is unknown.

When DMI is regulated by distention in the reticulorumen, substitution of NFFS for forages might increase DMI (Allen, 2000). However, Allen (2000) reviewed several studies with lactating cows and found that supple- 
Table 5. In situ DM and NDF digestion kinetics (mean \pm standard error) of oat hay, beet pulp, control diet, and beet pulp diet fed to Holstein cows and heifers during the close-up period

\begin{tabular}{|c|c|c|c|c|}
\hline \multirow[b]{2}{*}{ Item } & \multicolumn{2}{|c|}{ Ingredient } & \multicolumn{2}{|c|}{ Close-up diet } \\
\hline & Oat hay & Beet pulp & Control & Beet pulp \\
\hline \multicolumn{5}{|l|}{$\mathrm{DM}$} \\
\hline Lag, h & $4.07 \pm 1.97$ & $5.82 \pm 1.83$ & $2.24 \pm 1.32$ & $1.49 \pm 1.03$ \\
\hline $\mathrm{k}_{\mathrm{d}}{ }^{1} \mathrm{~h}^{-1}$ & $0.026 \pm 0.003$ & $0.089 \pm 0.014$ & $0.041 \pm 0.009$ & $0.034 \pm 0.003$ \\
\hline $\mathrm{PED}^{2} \%$ & $50.6 \pm 0.8$ & $89.7 \pm 0.4$ & $71.6 \pm 1.4$ & $77.0 \pm 0.7$ \\
\hline $\mathrm{R}^{2}$ & $0.94 \pm 0.03$ & $0.95 \pm 0.03$ & $0.98 \pm 0.01$ & $0.96 \pm 0.01$ \\
\hline \multicolumn{5}{|l|}{ NDF } \\
\hline Lag, h & $5.08 \pm 2.10$ & $6.22 \pm 2.09$ & $6.54 \pm 1.99$ & $2.83 \pm 1.35$ \\
\hline $\mathrm{k}_{\mathrm{d}}, \mathrm{h}^{-1}$ & $0.026 \pm 0.003$ & $0.088 \pm 0.018$ & $0.039 \pm 0.010$ & $0.030 \pm 0.004$ \\
\hline PED, \% & $51.7 \pm 0.8$ & $85.3 \pm 0.5$ & $64.9 \pm 2.3$ & $71.9 \pm 0.5$ \\
\hline $\mathrm{R}^{2}$ & $0.94 \pm 0.03$ & $0.94 \pm 0.03$ & $0.98 \pm 0.01$ & $0.96 \pm 0.01$ \\
\hline
\end{tabular}

${ }^{1}$ Fractional rate of digestion.

${ }^{2}$ Potential extent of digestion at $96 \mathrm{~h}$ of in situ fermentation.

menting NFFS for forage had an inconsistent effect on DMI of lactating cows; DMI increased in $16 \%$ of comparisons, decreased in $6 \%$ of comparisons, and had no effect in $77 \%$ of comparisons. In contrast, the effect of substitution of NFFS for forages on DMI has been more positive in studies with dry cows fed bulky diets (Underwood et al., 1998; Pickett et al., 2003) where DMI may be decreased in part by physical compression of the rumen by the gravid uterus (Ingvartsen and Andersen, 2000). However, Park et al. (2001) found, by measuring ruminal water-holding capacity at different times prepartum, that physical capacity of the rumen does not cause prepartum intake depression. Dry matter intake increased in the range of 1.5 to $3.5 \mathrm{~kg} / \mathrm{d}$ when NFFS was substituted for 15 to $45 \%$ of the forage (Underwood et al., 1998; Pickett et al., 2003). These results contrast with the current study where DMI was similar between dietary treatments. Possible reasons for the difference in results among studies include 1) source of nonforage fiber, 2) digestion kinetics and passage rate, and 3 ) forage quality.
The Underwood et al. (1998) and Pickett et al. (2003) studies used soybean hulls or soybean hulls plus cottonseed hulls, respectively, whereas the current study used beet pulp. Bhatti and Firkins (1995) found that beet pulp had a relatively low functional specific gravity, a greater rate of hydration, and a higher water-holding capacity than other NFFS, such as soybean hulls. The effects of those characteristics on rate of passage and DMI are unclear (Bhatti and Firkins, 1995; Firkins, 1997), but presumably NFFS would vary considerably in ruminal NDF digestibility because of differences in ruminal rate of passage. Thus, it is possible that digestion kinetics or passage rate NDF was different among the reported studies and influenced DMI.

The forage type and quality was not reported in detail in the abstracts by Underwood et al. (1998) and Pickett et al. (2003), but presumably the forage was poor to average quality. The oat hay used in this study was very palatable and of average quality (Table 2; Dairy One, 2006). Use of poorer quality forage may have yielded different results. Also, the replacement level of

Table 6. Dry matter intake, energy balance, and serum NEFA and BHBA concentration from $-5 \mathrm{~d}$ relative to actual parturition to parturition for Holstein cows and heifers fed either a control or beet pulp diet during the close-up period

\begin{tabular}{|c|c|c|c|c|c|c|}
\hline \multirow[b]{2}{*}{ Item } & \multicolumn{2}{|c|}{ Close-up diet } & \multirow[b]{2}{*}{ SE } & \multicolumn{3}{|c|}{$P$-value } \\
\hline & Control & Beet pulp & & Diet & Parity & Time \\
\hline DMI, \% of BW/d & 1.52 & 1.43 & 0.07 & 0.35 & 0.13 & $<0.001$ \\
\hline DMI, kg/d & 11.4 & 10.9 & 0.5 & 0.44 & 0.004 & $<0.001$ \\
\hline DMI change, ${ }^{1} \mathrm{~kg}$ & -1.5 & -3.2 & 0.7 & 0.08 & 0.81 & - \\
\hline Energy balance, ${ }^{2} \%$ & 120 & 112 & 5 & 0.31 & 0.08 & $<0.001$ \\
\hline \multicolumn{7}{|l|}{ Serum } \\
\hline NEFA, $\mu E q / L$ & 396 & 366 & 40 & 0.60 & 0.49 & $<0.001$ \\
\hline $\mathrm{BHBA}, \mathrm{mg} / \mathrm{dL}$ & 5.7 & 6.2 & 0.2 & 0.15 & $0.89^{\mathrm{a}}$ & $<0.001$ \\
\hline
\end{tabular}

${ }^{\text {a}}$ Parity $\times$ time was significant $(P<0.05)$.

${ }^{1}$ Change $=-5 \mathrm{~d}$ relative to actual parturition minus $-1 \mathrm{~d}$ relative to actual parturition value.

${ }^{2}$ Percentage of $\mathrm{NE}_{\mathrm{L}}$ requirement. 
Table 7. Body condition score and BW during the close-up period for Holstein cows and heifers fed either a control or beet pulp diet during the close-up period

\begin{tabular}{|c|c|c|c|c|c|c|}
\hline \multirow[b]{2}{*}{ Item } & \multicolumn{2}{|c|}{ Close-up diet } & \multirow[b]{2}{*}{$\mathrm{SE}$} & \multicolumn{3}{|c|}{$P$-value } \\
\hline & Control & Beet pulp & & Diet & Parity & Time \\
\hline BCS & 3.54 & 3.57 & 0.02 & 0.29 & 0.56 & 0.06 \\
\hline BCS $_{\text {change }}{ }^{1}$ & 0.01 & 0.07 & 0.03 & 0.20 & 0.70 & - \\
\hline $\mathrm{BW}, \mathrm{kg}$ & 773 & 778 & 3 & 0.34 & $0.64^{\mathrm{a}}$ & $<0.001$ \\
\hline BW change, $\mathrm{kg}$ & 13 & 20 & 5 & 0.30 & 0.25 & - \\
\hline
\end{tabular}

${ }^{\text {aParity }} \times$ time tended to be significant $(P<0.10)$.

${ }^{1} \mathrm{Wk}-1$ relative to expected parturition value minus start of study value.

$50 \%$ oat hay (15\% of diet DM) with NFFS may have been too low given that the control and beet pulp diets contained $10 \%$ soybean hulls. If beet pulp made up 30\% of the diet DM and replaced all the oat hay there may have been a DMI response. Replacement of 28 to $30 \%$ of forage with NFFS has positively affected DMI in other studies (Underwood et al., 1998; Pickett et al., 2003).

During the close-up period, diet did not affect mean BCS (3.56; $P=0.29$; Table 7) or BW (776 kg; $P=0.34$; Table 7). The short time period would not likely allow any observed changes in BCS. However, there was a trend for an increase in BCS over time $(P=0.06$; Table 7 ), but the change ( $P=0.20$; Table 7$)$ was less than 0.1 point and not biologically significant. There was a small increase $(<20 \mathrm{~kg})$ in BW as parturition approached $(P<$ 0.001 ; Table 7). This was expected as BW gain occurred from an increase in weight of the fetus, fluids, fetal membranes, and uterus (Bereskin and Touchberry, 1967) and positive energy balance (Table 6). There was a trend for an interaction of parity and time for BW $(P=0.09$; Table 7) indicating that heifers gained $\mathrm{BW}$ at a faster rate than cows as parturition approached. Presumably, heifers were gaining additional weight from their growth. However, this does not agree with the observation of no effect of parity on BW change $(P=$ 0.25 ; Table 7). The discrepancy may be explained by having only 4 heifers with a low BW on the study for greater than $21 \mathrm{~d}$ and thereby biasing the parity by time effect. Typically, BW of heifers is less than BW of cows before parturition. The parity effect on BW was not observed in this study because BW data were adjusted by covariance analysis using BW at the start of the study.

Total tract digestibility of $\mathrm{DM}, \mathrm{OM}, \mathrm{CP}, \mathrm{ADF}, \mathrm{NDF}$, and starch in the close-up diets was not different (Table 8). The absence of a treatment response for total tract digestibility of nutrients supports the lack of an intake response during the close-up period. Neither Underwood et al. (1998) nor Pickett et al. (2003) measured digestion kinetics or total tract digestibility. In general, NFFS have a large amount of potentially degradable NDF as was observed in this study when in situ assays were conducted with oat hay and beet pulp (Table 5). However, NFFS have a small particle size and high specific gravity allowing large amounts of potentially available NDF to pass out of the rumen, therefore lowering ruminal NDF digestibility (Firkins, 1997; Grant, 1997). There is a potential to shift NDF digestion to the hindgut (Firkins, 1997) with NFFS. This shift may have resulted in similar total tract NDF digestibility.

\section{Postpartum Performance}

Calf birth weight was similar $(P=0.15)$ for animals fed the control $(43.6 \pm 1.0 \mathrm{~kg})$ and beet pulp diets $(45.7$ $\pm 1.0 \mathrm{~kg}$ ). All animals gave birth to a single calf (i.e., no twins). Birth weight of calves was approximately 4 $\mathrm{kg}$ greater $(P=0.006)$ for cows than heifers.

Table 8. Total tract digestibility (\%) of DM, OM, CP, ADF, NDF, and starch in the close-up control and beet pulp diets fed to Holstein cows and heifers

\begin{tabular}{|c|c|c|c|c|c|c|}
\hline \multirow[b]{2}{*}{ Item } & \multicolumn{2}{|c|}{ Close-up diet } & \multirow[b]{2}{*}{ SE } & \multicolumn{3}{|c|}{$P$-value } \\
\hline & Control & Beet pulp & & Diet (D) & Parity $(\mathrm{P})$ & $\mathrm{D} \times \mathrm{P}$ \\
\hline DM & 69.5 & 71.2 & 1.2 & 0.33 & 0.001 & 0.54 \\
\hline $\mathrm{OM}$ & 71.9 & 73.9 & 1.2 & 0.26 & 0.002 & 0.55 \\
\hline CP & 67.3 & 65.3 & 2.2 & 0.54 & 0.04 & 0.52 \\
\hline $\mathrm{ADF}$ & 54.8 & 58.3 & 1.7 & 0.16 & 0.006 & 0.19 \\
\hline NDF & 55.3 & 58.7 & 1.8 & 0.19 & 0.007 & 0.42 \\
\hline Starch & 95.4 & 95.2 & 0.6 & 0.75 & 0.02 & 0.46 \\
\hline
\end{tabular}


Table 9. Dry matter intake, milk yield, energy balance, and serum NEFA and BHBA concentration from 1 to 7 DIM for Holstein cows and heifers fed either a control or beet pulp diet during the close-up period

\begin{tabular}{|c|c|c|c|c|c|c|}
\hline \multirow[b]{2}{*}{ Item } & \multicolumn{2}{|c|}{ Close-up diet } & \multirow[b]{2}{*}{ SE } & \multicolumn{3}{|c|}{$P$-value } \\
\hline & Control & Beet pulp & & Diet & Parity & Time \\
\hline DMI, $\%$ of BW/d & 2.09 & 2.00 & 0.09 & 0.46 & 0.02 & $<0.001$ \\
\hline DMI, kg/d & 14.6 & 13.9 & 0.5 & 0.43 & $<0.001$ & $<0.001$ \\
\hline DMI change, ${ }^{1} \mathrm{~kg}$ & 1.3 & 3.1 & 0.6 & 0.03 & 0.69 & - \\
\hline Milk, kg/d & 31.4 & 31.4 & 0.9 & $0.97^{\mathrm{a}}$ & $<0.001^{\mathrm{b}}$ & $<0.001$ \\
\hline Energy balance, ${ }^{2} \%$ & 71 & 69 & 3 & 0.60 & 0.49 & $<0.001$ \\
\hline Serum & & & & & & \\
\hline NEFA, $\mu \mathrm{Eq} / \mathrm{L}$ & 760 & 731 & 72 & 0.77 & 0.02 & 0.99 \\
\hline BHBA, mg/dL & 10.3 & 11.1 & 1.2 & 0.61 & 0.55 & $<0.001$ \\
\hline
\end{tabular}

${ }^{\text {a Diet }} \times$ parity tended to be significant $(P<0.10)$.

${ }^{\mathrm{b}}$ Parity $\times$ time tended to be significant $(P<0.10)$.

${ }^{1} 7$ DIM value minus 1 DIM value.

${ }^{2}$ Percentage of $\mathrm{NE}_{\mathrm{L}}$ requirement.

There was no carryover effect of the close-up diet on DMI, energy balance, milk yield and composition, or serum content of NEFA and BHBA during the first 7 DIM $(P>0.10$; Table 9$)$ or 14 DIM $(P>0.10$; Tables 10 and 11). A carryover effect of close-up diet on postpartum variables was not expected because the close-up diet did not affect $(P>0.10)$ prepartum intake (Table 6 ), metabolism (Table 6), or total tract digestibility (Table 8). There was a diet by time interaction for DMI during the first 14 DIM ( $P=0.05$; Table 10; Figure 1$)$. Animals fed the control and beet pulp diets increased DMI 35 and $47 \%$, respectively (Figure 1). Animals fed the beet pulp diet had a smoother and more gradual increase in DMI compared with animals fed the control diet. Observationally, the dip in DMI at 4 to 7 DIM for the cannulated control cows corresponded to a change in consistency of the ruminal digesta mat with a visual decrease in long oat hay particles in the mat.

There was a diet by parity interaction for milk yield during the first 7 DIM ( $P=0.05$; Table 9$)$ and 14 DIM $(P=0.07$; Table 10; Figure 2$)$. More milk was produced when, during the close-up period, cows were fed the control diet and heifers were fed the beet pulp diet. Milk component yield followed a similar pattern to milk yield (Table 11). The reason for the different response to prepartum diet by parity is unknown but it is supported by the diet by parity interaction for BW loss $(P=$ 0.02 ; Table 10). More BW was lost in the first 14 DIM by cows previously fed the control diet ( $-65 \mathrm{vs} .-37 \mathrm{~kg}$ of BW) and heifers previously fed the beet pulp diet

Table 10. Body condition score, BW, DMI, milk yield, energy balance, and serum NEFA and BHBA concentration from 1 to 14 DIM for Holstein cows and heifers fed either a control or beet pulp diet during the closeup period

\begin{tabular}{|c|c|c|c|c|c|c|}
\hline \multirow[b]{2}{*}{ Item } & \multicolumn{2}{|c|}{ Close-up diet } & \multirow[b]{2}{*}{ SE } & \multicolumn{3}{|c|}{$P$-value } \\
\hline & Control & Beet pulp & & Diet & Parity & Time \\
\hline $\mathrm{BCS}$ & 3.30 & 3.33 & 0.02 & 0.40 & 0.55 & $<0.001$ \\
\hline BCS change $^{1}$ & -0.36 & -0.30 & 0.05 & 0.42 & 0.48 & - \\
\hline $\mathrm{BW}, \mathrm{kg}$ & 691 & 690 & 5 & 0.91 & 0.52 & $<0.001$ \\
\hline $\mathrm{BW}$ change, ${ }^{1} \mathrm{~kg}$ & -63 & -55 & 6 & $0.34^{\mathrm{a}}$ & 0.10 & - \\
\hline DMI, $\%$ of BW/d & 2.21 & 2.18 & 0.09 & $0.78^{b}$ & 0.02 & $<0.001$ \\
\hline DMI, kg/d & 15.0 & 14.9 & 0.6 & $0.82^{b}$ & $<0.001$ & $<0.001$ \\
\hline DMI change ${ }^{2} \mathrm{~kg}$ & 3.4 & 4.5 & 0.6 & 0.18 & 0.49 & - \\
\hline Milk, kg/d & 34.4 & 34.9 & 0.9 & $0.68^{\mathrm{c}}$ & $<0.001$ & $<0.001$ \\
\hline Energy balance, ${ }^{3} \%$ & 69 & 68 & 3 & 0.84 & 0.64 & $<0.001$ \\
\hline \multicolumn{7}{|l|}{ Serum } \\
\hline NEFA, $\mu \mathrm{Eq} / \mathrm{L}$ & 744 & 702 & 61 & 0.62 & 0.008 & 0.17 \\
\hline BHBA, $\mathrm{mg} / \mathrm{dL}$ & 12.6 & 12.6 & 1.6 & 0.99 & 0.22 & $<0.001$ \\
\hline
\end{tabular}

${ }^{a}$ Diet $\times$ parity was significant $(P<0.05)$.

${ }^{\mathrm{b}}$ Diet $\times$ time tended to be significant $(P<0.10)$.

${ }^{\mathrm{c}}$ Diet $\times$ parity tended to be significant $(P<0.10)$.

${ }^{1} 14$ DIM value minus parturition value.

${ }^{2} 14$ DIM value minus 1 DIM value.

${ }^{3}$ Percentage of $\mathrm{NE}_{\mathrm{L}}$ requirement. 
Table 11. Sample day ${ }^{1}$ milk yield and composition for Holstein cows and heifers fed either a control or beet pulp diet during the close-up period

\begin{tabular}{|c|c|c|c|c|c|c|}
\hline \multirow[b]{2}{*}{ Item } & \multicolumn{2}{|c|}{ Close-up diet } & \multirow[b]{2}{*}{$\mathrm{SE}$} & \multicolumn{3}{|c|}{$P$-value } \\
\hline & Control & Beet pulp & & Diet (D) & Parity (P) & $\mathrm{D} \times \mathrm{P}$ \\
\hline Milk $_{\text {sample dav }}, \mathrm{kg} / \mathrm{d}$ & 37.0 & 38.9 & 1.1 & 0.20 & $<0.001$ & 0.05 \\
\hline Fat, \% & 4.61 & 4.46 & 0.12 & 0.38 & 0.67 & 0.82 \\
\hline Fat, kg/d & 1.70 & 1.73 & 0.06 & 0.68 & $<0.001$ & 0.06 \\
\hline True protein, \% & 3.29 & 3.25 & 0.05 & 0.52 & 0.009 & 0.32 \\
\hline True protein, kg/d & 1.22 & 1.26 & 0.04 & 0.45 & $<0.001$ & 0.02 \\
\hline Lactose, $\%$ & 4.77 & 4.81 & 0.04 & 0.37 & 0.71 & 0.34 \\
\hline Lactose, kg/d & 1.76 & 1.87 & 0.05 & 0.15 & $<0.001$ & 0.04 \\
\hline $\mathrm{SNF}, \%$ & 8.94 & 8.94 & 0.06 & 0.98 & 0.11 & 0.27 \\
\hline $\mathrm{SNF}, \mathrm{kg} / \mathrm{d}$ & 3.31 & 3.47 & 0.10 & 0.23 & $<0.001$ & 0.03 \\
\hline Urea N, mg/dL & 12.6 & 12.3 & 0.4 & 0.61 & 0.38 & 0.25 \\
\hline $\mathrm{SCS}^{2}$ & 2.4 & 2.4 & 0.2 & 0.99 & 0.16 & 0.80 \\
\hline
\end{tabular}

${ }^{1}$ Milk was sampled from 3 consecutive milkings for each animal between 7 to 10 DIM and 11 to 14 DIM. Results were the average of the 2 sampling periods.

${ }^{2} \mathrm{SCS}=\left\{\left[\log _{10}(\mathrm{SCC} / 1,000)-2\right] / \log _{10}(2)\right\}+3$.

( -73 vs. $-61 \mathrm{~kg}$ of BW). Cows were in negative energy balance (Tables 9 and 10) during the first 14 DIM and mobilized body reserves from adipose and muscle tissue indicated by loss of BCS and BW (Table 10) and elevated serum NEFA and BHBA (Tables 9 and 10). The number of cows with at least $1 \mathrm{~d}$ of ketonemia (BHBA $\geq 14.4$ $\mathrm{mg} / \mathrm{dL}$ ) during 1 to 14 DIM was 15 of 31 cows fed the control diet and 14 of 33 cows fed the beet pulp diet (Table 12). The frequency of individual health disorders was not affected by close-up diet $(P>0.10$; Table 12$)$. Given the lack of dietary treatment effect on prepartum and postpartum metabolism and performance, no difference in the frequency of health disorders was expected.

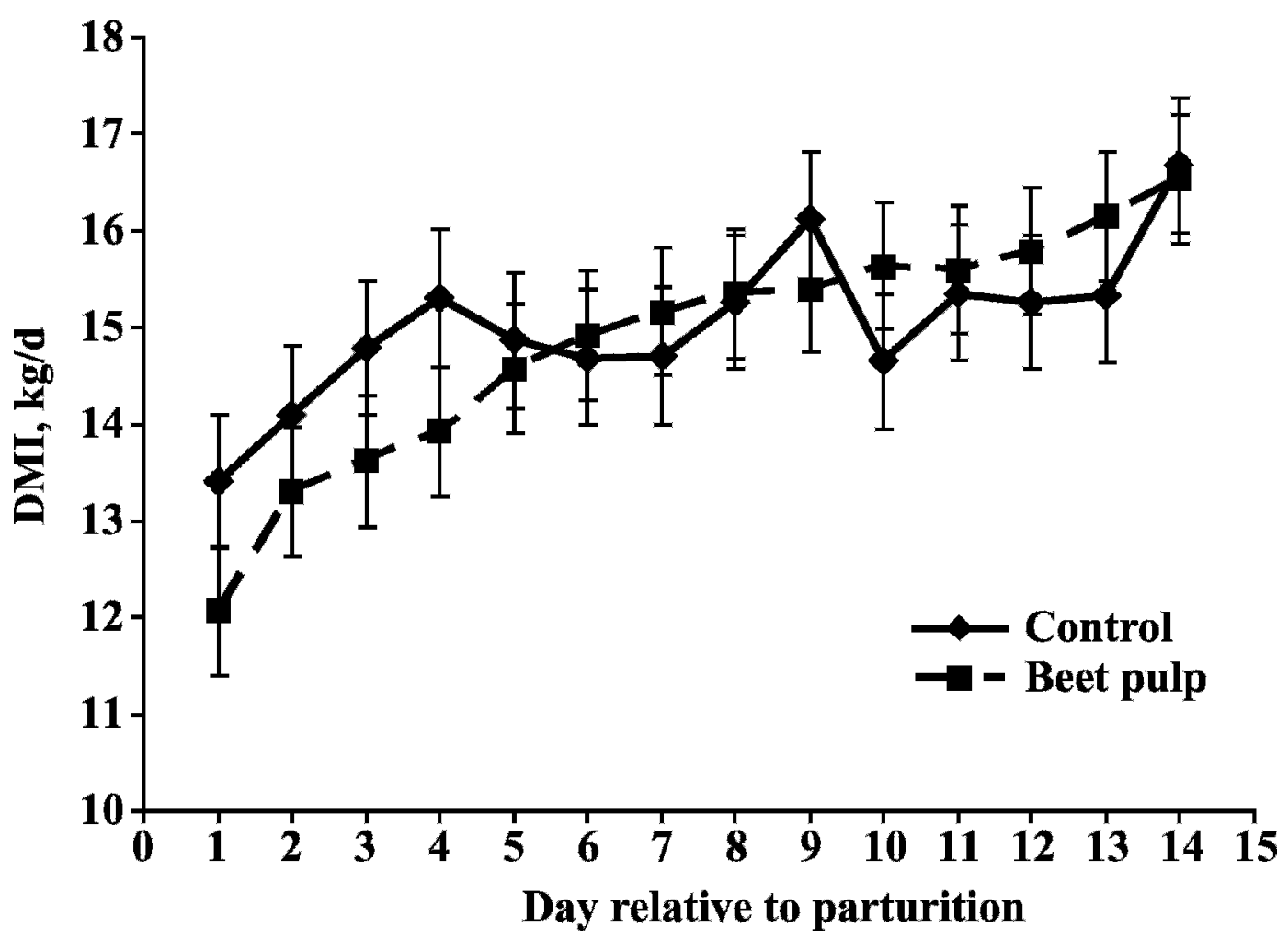

Figure 1. Dry matter intake for the first $14 \mathrm{~d}$ postpartum of cows and heifers fed either a control or beet pulp diet during the close-up period (diet by time interaction: $P=0.05$ ). 


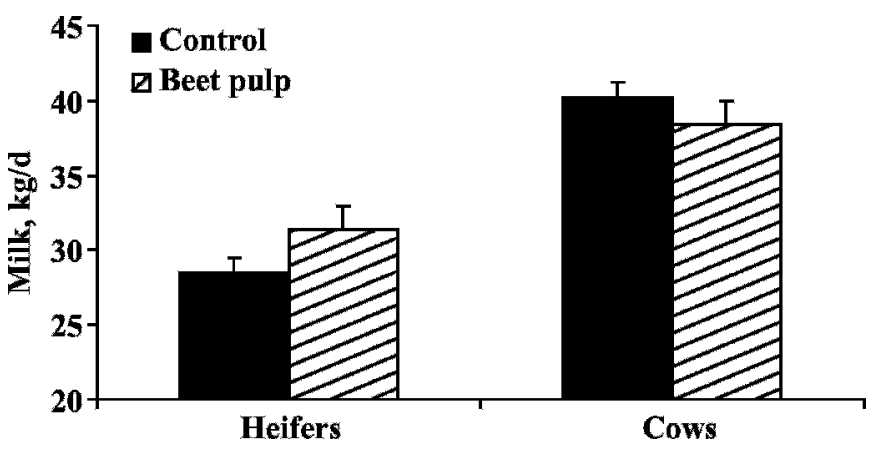

Figure 2. Average milk yield for the first $14 \mathrm{~d}$ postpartum of cows and heifers fed either a control or beet pulp diet during the close-up period (diet by parity interaction: $P=0.07$ ).

\section{CONCLUSIONS}

Partial replacement of forage NDF (oat hay) with byproduct NFFS NDF (beet pulp) in close-up diets did not affect periparturient intake, metabolism, or performance. Total tract digestibility of nutrients in the diets was similar. Factors that may have affected the outcome of this study compared with other studies include

Table 12. Frequency ${ }^{1}$ of health disorders from 1 to 14 DIM for Holstein cows and heifers fed either a control or beet pulp diet during the close-up period

\begin{tabular}{|c|c|c|c|}
\hline \multirow[b]{2}{*}{ Item } & \multicolumn{2}{|c|}{ Close-up diet } & \multirow[b]{2}{*}{$P$-value } \\
\hline & Control & Beet pulp & \\
\hline Milk fever & 0 & 1 & 0.99 \\
\hline Displaced abomasum & 2 & 1 & 0.61 \\
\hline \multicolumn{4}{|l|}{ Ketosis $^{2}$} \\
\hline Subclincal, ${ }^{3}$ not treated & 16 & 19 & 0.80 \\
\hline Subclinical, treated ${ }^{4}$ & 5 & 2 & 0.25 \\
\hline Clinical $^{5}$ & 1 & 0 & 0.48 \\
\hline Ketonemia $^{6}$ & 15 & 14 & 0.80 \\
\hline Retained placenta & 4 & 5 & 0.99 \\
\hline Metritis & 2 & 1 & 0.61 \\
\hline Mastitis & 2 & 1 & 0.61 \\
\hline Foot and leg problems ${ }^{7}$ & 3 & 4 & 0.99 \\
\hline Total health disorders ${ }^{8}$ & 35 & 34 & - \\
\hline
\end{tabular}

${ }^{1}$ Number of animals with at least one incidence.

${ }^{2}$ The most severe ketosis incidence was recorded for each animal.

${ }^{3}$ Animal had ketosuria at least $1 \mathrm{~d}$ (determined using a reagent strip for urinalysis).

${ }^{4}$ Propylene glycol given by mouth or dextrose given by intravenous injection.

${ }^{5}$ Animal had ketosuria and showed signs of anorexia, ataxia, or abnormal behavior.

${ }^{6}$ Animal had serum BHBA $\geq 14.4 \mathrm{mg} / \mathrm{dL}$ at least $1 \mathrm{~d}$ during 1 to 14 DIM.

${ }^{7}$ Includes general lameness, abscess, pododermatitis circumscripta (ulcer), interdigital hyperplasia (corn), interdigital phlegmon (foot rot), digital dermatitis, and white line disease.

${ }^{8}$ Summation of the frequencies of hypocalcemia, displaced abomasum, subclinical ketosis (not treated and treated), clinical ketosis, retained placenta, metritis, mastitis, and foot and leg problems. source of nonforage fiber, digestion kinetics and passage rate of NFFS, and forage quality. Further investigation of forage replacement level with alternative NFFS is needed. In addition, more information is needed to characterize how physical and chemical properties of NFFS will interact with other feedstuffs to affect digestion kinetics, passage rate, and feed intake during the transition period.

\section{ACKNOWLEDGMENTS}

This work was supported in part by a grant from ZenNoh National Federation of Agricultural Co-operative Associations (Tokyo, Japan). The authors are grateful to the Miner Institute dairy farm staff, J. W. Darrah, S. A. Flis, C. T. Hill, and H. M. Wolford for their assistance with this study.

\section{REFERENCES}

Allen, M. S. 2000. Effects of diet on short-term regulation of feed intake by lactating dairy cattle. J. Dairy Sci. 83:1598-1624.

AOAC. 2000. Official Methods of Analysis. 17th ed. Association of Official Analytical Chemists, Arlington, VA

Bereskin, B., and R. W. Touchberry. 1967. Some effects of pregnancy on body weight and paunch girth. J. Dairy Sci. 50:220-224.

Bhatti, S. A., and J. L. Firkins. 1995. Kinetics of hydration and functional specific gravity of fibrous feed by-products. J. Anim. Sci. 73:1449-1458.

Dairy One. 2006. Feed composition library. http://www.dairyone.com/ Forage/FeedComp/Main_GetResults.asp Accessed Aug. 24, 2006.

Drackley, J. K. 1999. Biology of dairy cows during the transition period: The final frontier? J. Dairy Sci. 82:2259-2273.

Drackley, J. K. 2003. Interrelationships of prepartum dry matter intake with postpartum intake and hepatic lipid accumulation. J. Dairy Sci. 86(Suppl. 1):104-105. (Abstr.)

Ferguson, J. D., D. T. Galligan, and N. Thomsen. 1994. Principal descriptors of body condition score in Holstein cows. J. Dairy Sci. 77:2695-2703.

Firkins, J. L. 1997. Effects of feeding nonforage fiber sources on site of fiber digestion. J. Dairy Sci. 80:1426-1437.

Goering, H. K., and P. J. Van Soest. 1970. Forage Fiber Analysis (Apparatus, Reagents, Procedures, and Some Applications). Agriculture Handbook No. 379. ARS-USDA, Washington, DC.

Grant, R. J. 1997. Interactions among forages and nonforage fiber sources. J. Dairy Sci. 80:1438-1446.

Grummer, R. R. 1995. Impact of changes in organic nutrient metabolism on feeding the transition dairy cow. J. Dairy Sci. 73:28202833.

Hall, M. B., W. H. Hoover, J. P. Jennings, and T. K. Miller-Webster. 1999. A method for partitioning neutral detergent-soluble carbohydrates. J. Sci. Food Agric. 79:2079-2086.

Hatcher, L., and E. J. Stepanski. 1994. A Step-by-Step Approach to Using the SAS System for Univariate and Multivarate Statistics. SAS Institute Inc., Cary, NC.

Ingvartsen, K. L., and J. B. Andersen. 2000. Integration of metabolism and intake regulation: A review focusing on periparturient animals. J. Dairy Sci. 83:1573-1597.

Lammers, B. P., D. R. Buckmaster, and A. J. Heinrichs. 1996. A simple method for the analysis of particle sizes of forage and total mixed rations. J. Dairy Sci. 79:922-928.

Licitra, G., T. M. Hernandez, and P. J. Van Soest. 1996. Standardization of procedures for nitrogen fractionation of ruminant feeds. Anim. Feed Sci. Technol. 57:347-358.

Littell, R. C., G. A. Milliken, W. W. Stroup, and R. D. Wolfinger. 1996. SAS System for Mixed Models. SAS Institute Inc., Cary, NC. 
Mashek, D. G., and R. R. Grummer. 2003. Feeding pre-fresh transition cows: Should we maximize feed intake or minimize feed intake depression? J. Dairy Sci. 86 (Suppl. 2):11-12. (Abstr.)

Maynard, L. A., J. K. Loosli, H. F. Hintz, and R. G. Warner. 1979. Digestive processes in different species. Pages 21-46 in Animal Nutrition. McGraw-Hill, Inc., New York, NY.

Mertens, D. R., and J. R. Loften. 1980. The effect of starch on forage fiber digestion kinetics in vitro. J. Dairy Sci. 63:1437-1446.

NRC. 2001. Nutrient Requirements of Dairy Cattle. 7th rev. ed. National Academy Press, Washington, DC.

Park, A. F., J. E. Shirley, J. M. DeFrain, E. C. Titgemeyer, E. E. Ferdinand, R. C. Cochran, D. G. Schmidt, S. E. Ives, and T. G. Nagaraja. 2001. Changes in rumen capacity during the periparturient period in dairy cows. J. Dairy Sci. 84(Suppl. 1):82. (Abstr.)

Pickett, M. M., T. W. Cassidy, P. R. Tozer, and G. A. Varga. 2003. Effect of prepartum dietary carbohydrate source and monensin on dry matter intake, milk production and blood metabolites of transition dairy cows. J. Dairy Sci. 86(Suppl. 1):10. (Abstr.)

Roe, M. B., and C. J. Sniffen. 1990. Techniques for measuring protein fractions in feedstuffs. Pages 81-88 in Proc. Cornell Nutr. Conf., Rochester, NY. Cornell University, Ithaca, NY.
Sirois, P. K., M. J. Reuter, C. M. Laughlin, and P. J. Lockwood. 1994. A method for determining macro and micro elements in forages and feeds by inductively coupled plasma atomic emission spectrometry. Spectroscopist 3:6-9.

Smith, D. 1969. Removing and analyzing total nonstructural carbohydrates from plant tissue. Wisconsin Agric. Exp. Stn. Res. Rep. 41. Madison.

Smith, K. L., M. R. Waldron, J. K. Drackley, M. T. Socha, and T. R. Overton. 2005. Performance of dairy cows as affected by prepartum dietary carbohydrate source and supplementation with chromium throughout the transition period. J. Dairy Sci. 88:255-263.

Underwood, J. P., J. N. Spain, and M. C. Lucy. 1998. The effects of feeding soy hulls in transition cow diet on lactation and performance of Holstein dairy cows. J. Dairy Sci. 81(Suppl. 1):296. (Abstr.)

Van Soest, P. J., J. B. Robertson, and B. A. Lewis. 1991. Methods for dietary fiber, neutral detergent fiber, and nonstarch polysaccharides in relation to animal nutrition. J. Dairy Sci. 74:35833597.

Vazquez-Añon, M., S. Bertics, M. Luck, R. R. Grummer, and J. Pinheiro. 1994. Peripartum liver triglyceride and plasma metabolites in dairy cows. J. Dairy Sci. 77:1521-1528. 